\title{
legelivet
}

På disse sidene i Tidsskriftet - legelivet - finner du stoff om legers liv.

Her er det presentasjon av arbeidssteder, nyhetssaker, nye doktorgrader,

nye spesialister og minneord. Alt samlet på ett sted - så du kan følge enda bedre med.

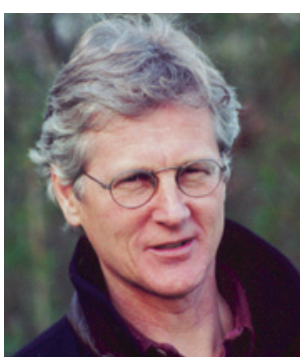

Karl Otto Nakken. Foto: Privat

Karl Otto Nakken (f. 1945) er lege ved Klinikk for kirurgi og nevrofag, Oslo universitetssykehus.

«Gjennom mine vel 40 år på norske sykehus har jeg møtt mange trivelige pasienter som har lært meg mye om å leve med kronisk sykdom»

\section{Om bunnlinjer og pasientavtaler}

\author{
I doktorklubben vår har vi mer enn én gang sukket høylytt over new \\ public management (NPM). Hvilken gauk var det som innførte dette \\ i norsk helsevesen? Var det Jens? I tilfelle ville vi ha invitert ham til \\ et klubbmøte og fortalt hva han har stelt i stand.
}

Ideen om å applisere tankegods hentet fra næringslivet på helsevesenet må skyldes total mangel på medisinsk innsikt. I industrien er standardisering og eliminering av variasjoner et ideal - for å øke produktiviteten, redusere kostnadene og utnytte stordriftsfordeler. En slik ideologi, som i sin natur er inhuman, vil aldri kunne passe i medisinen med dens biologiske mangfold. Hver pasient er unik og har krav på individualisert behandling. New public management er på kollisjonskurs med våre humanistiske og faglige idealer.

Kanskje Ibsen hadde helsebyråkrater i tankene når han lar Peer Gynt uttale: «Det står skrevet: det er ikke greit å forstå hvor skoen trykker når en ikke har den på»

I doktorklubben er vi enige om at innføringen av new public management i norsk helsevesen har vært en ulykke. Når bunnlinjen er viktigere enn kjerneoppgaven, nemlig pasientbehandlingen, mister man fort både engasjement og entusiasme. Jo flere pålegg fra helsebyråkratene, desto mindre tid til kjerneoppgavene. Dette tærer hardt på trivselen, og folk som mistrives, gjør en dårligere jobb.

Klinisk medisin er krevende, men også givende. Gjennom mine vel 40 år på norske sykehus har jeg møtt mange trivelige pasienter som har lært meg mye om å leve med kronisk sykdom. Ofte har jeg vært imponert over med hvilken fatning de har bøyd seg under sin skjebne.

Vi opplever alle pasienter som ikke møter til avtalt time. Noen er likevel mer pliktoppfyllende enn andre. En av mine pasienter fortalte under en kontrolltime at jeg hadde reddet livet hans. Jeg syntes selvfølgelig det var hyggelig, jeg trodde han tenkte på at han omsider var blitt anfallsfri etter mange år med stadig tilbakevendende epileptiske anfall.

Men nei, det hadde ikke noe med anfall å gjøre. Han fortalte han hadde en pram liggende ved Glåma (som Glomma kalles på hans hjemtrakter). På senhøsten var han på fisketur alene i prammen. Da han skulle ordne noe med fiskeutstyret, var han uheldig og falt i elven. Han gikk rett til bunns, han hadde gummistøvler og mye tøy på seg. Han tenkte: Nå drukner jeg. Men så kom han i tanker om at han hadde time hos meg til uken, og da fikk han ikke gitt beskjed om at han var druknet. Det kunne han ikke være bekjent av, og med sine siste krefter klarte han å kare seg til land! 